\title{
日循学術委員会 研究班報告
}

\section{心疾患運動療法に関する診療基準}

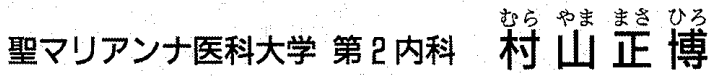

\section{はじめに}

本邦における心疾患の運動療法は，1950年代か ら木村登, 小林太刀夫らにより推進されてきたが, 1983年, 厚生省循環器病委託研究「心疾患のリ八 ビリテーションシステムに関する研究」(班長：戸 嶋裕徳)により，4 週間の心筋梗塞急性期 (AMI) リハビリテーション(リハ) 1の基本的骨子がまと められた。これにより, 本邦における AMIリ八は， 施設により多少のプログラムの内容に差が恋るも のの，基本的にはそれを踏襲した形で広く普及し ている。

心筋梗塞の運動療法は, 急性期の入院り八を第 1 期，ひき続いて行う社会復帰への 3 力月までの 通院を主体とした回復期運動療法を第 2 期，そし て，慢性期の在宅を中心とした二次予防のための 維持期運動療法である第 3 期運動療法に分けられ る. 大院り八は 4 週間プログラムが一般的であり， さらにそれを短縮化する検討が行われているが， その基本はすでに確立しているといってよい，し かし, 退院後の回復期扮よび慢性期の運動療法に ついてはその指針がない. 1989年，ようやく健康 保険において心筋梗塞に対する運動療法が発症か ら 3 力月に限り, 診療報酬の算定対象となったこ とから，ようやく回復期から維持期までの運動療 法を積極的に行う風潮が出てきた。

このような背景の下に，日本循環器学会では， 心疾患患者を対象とした退院後の回復期および慢
性期を中心とした運動療法に関する指針作成を目 的として，1988年より 3 年間「運動に関する診療 基準」委員会（委員および協力者：村山正博, 外 畑嬖, 紅露恒男, 道場信孝, 谷口興一, 斎藤宗靖, 藤田良範，岸田浩，太田壽城，川久保清，野原隆 司, 橋本通, 豊増功次, 川村孝, 武者春樹)，ひき 続いて1992年より「運動療法に関する診療基準」 委員会（委員抢よび協力者：村山正博, 外烟䉷, 道場信孝, 谷口興一, 斎藤宗靖, 藤田良範, 太田 壽城, 川久保清, 野原隆司, 豊増功次, 橋本遄, 川村孝，長山雅俊，武者春樹）を設置した。運動 療法指針の詳細については，両委員会の 6 年にわ たる一連の委員会報告書 2 6) 参照されたいが, こ こでは，委員会が行った「本邦における心疾患の 運動療法の現状」調查の結果と, 今後の問題点に ついて述べることとする.

\section{本邦医療機関における 心疾患運動療法の実態調査 ${ }^{4}$}

本邦における心疾患運動療法の実態を知るため に，本委員会では，平成 2 年に全国の国立病院， 大学附属病院および日本循環器学会指定研修病院 などの循環器疾患を専門とする施設 (448施設)に アンケート調査を行った。166施設 $(34 \%)$ より有 効回答が得られた。

院内または施設内の運動療法のみを行っている 施設が大半 $(73.9 \%)$ であり，在宅運動療法を施 行している施設は，43施設 $(26.1 \%)$, 院内および

[key words] 運動療法, 心筋梗塞慢性期, 心臟リハビリテーション 
在宅運動療法の両者を行っている施設は26施設 (15.8\%)であった。また，院内運動療法の $89.2 \%$ は，監視型運動療法であった。

\section{1. 院内運動療法}

院内運動療法を行っている148施設の中で, 運動 療法の専用施設を有子るのは61施設 $(41.2 \%)$ であ ったが，体育館または屋内運動施設を有している のは26施設(17.6\%)のみであった。運動施設をも たない87施設では, 病棟内 (45施設) や検查室 $(24$ 施 設)で施行している施設が多かった。院内運動療法 の平均期間は $1.6 \pm 1.3$ 力月であり，冠動脈疾患で は短く，冠危険因子に対する場合は長い傾向であ った，運動療法として行われている運動種目は， 歩行〜ジョギング，トレッドミル，自転車エルゴ メータが主であり，スポーツ運動療法として球技 を取り入れている施設は 2 施設のみであった。

運動療法において，運動強度を一定に保つよう にしている施設は約半数以下 $(42.6 \%)$ であった が，心電図モニタ一監視は，全員または一部の対 象者を合わせ $96.8 \%$ 施設で行われていた。また， 運動療法後に栄養指導や禁煙指導などの教育, 啓 蒙活動を $48.6 \%$ の施設で施行していた。運動療法 のスタッフとしては，医師(116施設)，看護婦(66 施設) が多く，理学療法士，看護婦，栄養士，体 育指導者の参加を希望する施設が多かった。

\section{2. 在宅運動療法}

在宅運動療法を行っている施設は45施設であっ た。対象疾患の大半は冠動脈疾患であり，平均期 間は3.4 1 1.6力月であった。運動種目は，大半が 歩行〜ジョギングであり，55.6\%の施設では，運 動強度を一定に保つよう指導していた。教育，啓 蒙活動は $97.5 \%$ の施設で行われていた。 スタッフ としては, 医師 (29施設), 理学療法士 ( 6 施設), 体育指導者 ( 4 施設)の順であった。

現在，本邦における心疾患運動療法は，院内運 動療法が主体であるが，在宅運動療法は，院内運 動療法に比べ施行施設数は少なく, 院内運動療法 から継続して行っている施設は，さらに少ない 17
施設 $(10.3 \%)$ のみであった。回復期・維持期の院 内運動療法が，施設やスタッフの不足，財政的理 由により現在十分に行われているとは言えない状 況であり，今後は在宅運動療法が院内運動療法か ら発展的に継続するシステムの構築が望まれる。 さらに，現在の運動療法は医師が中心となって行 われているが，実際の運動指導は運動生理の専門 家が必要である。本邦の運動療法の特徵の一つと して，運動の専門家である体育学部出身者の現場 への参加がそしく，多くは理学療法士の手によっ てなされているが，運動療法を広く行っていくた めには，諸外国のように，認定資格制度を導入し て運動療法の専門家の育成が必要と考之られる.

\section{心疾患運動療法の問題点}

上述の調査からも判るように，マンパワー不足 および専門施設の不足が大きな問題である。後者 の原因の一つとして，心疾患運動療法の施設基準 がある. 現在, 心疾患のリ八料は, 平成 6 年 4 月 の改訂により, AMI 発症から 3 力月に限り490点(昭 和63年には335点であった)が算定できるようにな った。しかし，心疾患のリ八を保險算定するには， 厳しい施設基準が設けられている。施設基準につ いては厚生省保険局医療課の出している「医科点 数の解釈」のリ八の項 (平成 6 年版，387頁) を参 照して頂きたいが，上述のアンケート調査におい て113施設の意見を集約した結果では注，平成元年 当時，心疾患運動療法の施設認定を受けていた施 設はわずか 12 施設 $(10.2 \%) て ゙ あ り ，$ 認定を受けて いない101施設の中の93施設は，今後認定を受ける ことを希望していた。

しかし，施設基準にある CCU，ICUの承認が必 要との規定に対しては，73施設が「厳しすぎる」 または「不要である」との意見であった，その理 由としては, CCU・ICUの設置や維持のための採 算性, 専任スタッフの不足, 中小病院では設置が 不可能などが挙げられた。また，運動療法施設と して, 専任の医師，および理学療法士または看護 婦の尃従が必要であり, さらに各種機器・器材を 揃える規定, スタッフの確保が困難などの理由で, 
「笓しすぎる」との意見が75施設 $(66.4 \%)$ を占め た。保険料算定では，3 月までとする規定は短 すぎるとの意見が74施設 (65.4\%)からあり，期間 としては半年〜 1 年が必要であると考えている施 設が多かった。

また，現在，AMIのみが対象疾患として認定さ れているが,他に狭心症 (76.1\%), CABG 後 $(79.6$ $\%)$ ，高脂血症 (79.6\%) などを適応疾患として運 動療法が必要であるとの意見が多かった。保険点 数(平成元年の335点)に対しては，「低すぎる」と の意見が86施設 $(79.6 \%)$ あり，実際の経費から勘 案する希望の平均点数は 1,100 点であった。

さらに, 現在の心疾患運動療法の施設基準では, CCU や ICU をもつ限られた施設のみが認定基準を 満たす状況であり，心疾患の運動療法を広く行う ためには，施設基準の緩和が必要と考えられる。 また，保険点数においても人件費，施設への投資，
採算性からは不十分と考えられ，各施設からの希 望と現状とはかなりの開きがあることも，心疾患 運動療法の発展を阻害している要因の一つとなっ ている，心疾患の運動療法としては心筋梗塞急性 期に限らず，冠危険因子や術後なども含めた総合 的な運動療法へと発展させることが，運動療法普 及への道と考えられる。

本邦における心疾患運動療法は, 欧米諸国に比 べると 20 年遅れていると言われている.AMIリ八 が一般に普及した現在, 今後は回復期から維持期 の運動療法を，本邦の実情に即したシステムとし て構築する時である。心疾患患者の QOL 向上は社 会的要求であり, 本委員会から示された心疾患運 動療法指針を基に，限られた施設ではなく，多く の施設が心疾患運動療法に目を向け，安全に広く 行われていくことが望まれる.

1）厚生省循環器病研究委託費による心疾患の!ハビ リテーションシステム開発に関する研究。昭和 57 年度研究実績集 (班長：戸嶋裕徳)。1982

2）運動負荷試験に関する䛦療基準：日本循環器学会 「運動に関する診療基準」委員会（委員長：村山 正博)，1988年度報告

3 ）運動療法に関する診療基準：同上，1989年度報告

\section{献}

4）医療機関における心疾患患者の運動療法に関する 実態調查：日本循環器学会「心疾患の運動療法に 関する診療基準」委員会 (委員長：村山正博), 1991 年度報告

5 ）健康増進施設実態調査：同上，1991年度報告

6）心疾患運動療法施設基準に関する調査：同上, 1992年度報告 